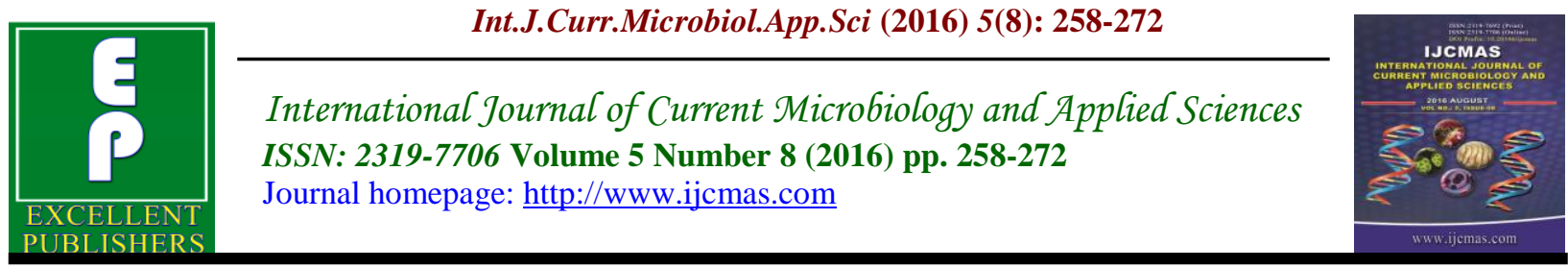

Original Research Article

http://dx.doi.org/10.20546/ijcmas.2016.508.027

\title{
Evaluation of Bioremediation Potential of Isolated Bacterial Culture YPAG-9 (Pseudomonas aeruginosa) for Decolorization of Sulfonated di-azodye Reactive Red HE8B under Optimized Culture Conditions
}

\author{
Yogesh Patel ${ }^{1 *}$ and Akshaya Gupte ${ }^{2}$ \\ ${ }^{1}$ Department of Microbiology, College of Basic Science and Humanities, Sardarkrushinagar, \\ Dantiwada Agricultural University (SDAU), Sardarkrushinagar, 385 506, Gujarat, India \\ ${ }^{2}$ Department of Microbiology, Natubhai V. Patel College of Pure and Applied Sciences, \\ VallabhVidyanagar, Anand 388 120, Gujarat, India \\ *Corresponding author
}

\begin{abstract}
A B S T R A C T
Keywords

Reactive Red

HE8B,

decolorization,

Pseudomonas

aeruginosa,

Optimization.

Article Info

Accepted:

12 July 2016

Available Online:

10 August 2016

Wastewater from textile industries poses a high environmental impact and therefore needs to be treated before being discharged into the environment. The present study deals with the decolorization of sulfonated di-azo dye Reactive Red HE8B by different bacterial cultures isolated from a contaminated site. Amongst 19 cultures, the isolate YPAG-9 displayed 86\% decolorization of Reactive Red HE8B (100 mg $\mathrm{l}^{-1}$ ) in $48 \mathrm{~h}$. Based on morphological, cultural, physiological and biochemical properties, the isolate YPAG-9 was identified as Pseudomonas aeruginosa. The color removal efficiency of the isolate was further improved by optimizing various physico-chemical parameters. The decolorization of the dye was 1.9 times higher under static condition as compared to shaking condition. The $10 \%(\mathrm{v} / \mathrm{v})$ inoculum size, $7.0 \mathrm{pH}$ and $30^{\circ} \mathrm{C}$ temperature were found optimum for the decolorization of the dye. The isolate was able to decolorize the dye in the range of 50-300 $\mathrm{mg} \mathrm{l}^{-1}$. The decolorization of 11 different synthetic dyes was achieved by the isolate YPAG-9. The results suggest the potential application of the isolate YPAG-9 for the bio-treatment of dye containing industrial waste waters.
\end{abstract}

\section{Introduction}

In recent years textile and dyestuff industries are considered as one of the main sources of water pollution problems owing to discharge of large amount of highly colored effluents to neighboring water bodies (Przystas et al., 2012). This negative anthropogenic impact on the environment is mainly associated with different dyes and their application to color synthetic and natural fabrics. Amongst different dye classes, azo dyes represent the largest class of dyes with diverse applicability in various industries namely paper, plastic, leather, food, pharmaceutical, cosmetics etc. (Liu et al., 2004). Their presence in the effluents adversely affects water sources, soil fertility, aquatic life and ecosystem integrity (Chen et al., 2011). Moreover, many dyes and their breakdown products cause significant human health problems due to toxigenic, mutagenic and 
carcinogenic effects (Gnanapragasam et al., 2010, Mangaiyarkarasi et al., 2015). Therefore their release into surface water is aesthetically undesirable and has gained considerable attention of environmental regulatory agencies as well as strict governmental legislation to evaluate the fate of dyes from industrial wastewater as well as from the natural environment (Flores et al., 2008; Liao et al., 2013).

Various physico-chemical methods like filtration, coagulation-flocculation, use of activated carbon, ozonation, adsorption, ion exchange etc are available for the treatment of dye containing wastewaters (Saratale et al., 2011; Ekambaram et al., 2016). However, the use of such processes is associated with certain technical and economical downsides (Franciscon et al., 2009; Lang et al., 2014). Therefore, bioremediation using different microbial agents presents an effective, cheaper and environmentally begin alternative for the treatment of dye containing industrial effluents (Ali, 2010). Different types of microorganisms including bacteria, fungi, actinomycetes, yeasts, algae have been reported for their ability to decolorize and mineralize various dyes under certain environmental conditions (Machado et al., 2006; Pajot et al., 2011; Gahlout et al., 2013; Rudakiya and Pawar 2014). In particular, the role of diverse groups of pure and mixed cultures of bacteria in the decolorization of textile dyes has been extensively investigated (Khouni et al., 2011; Kadam et al., 2013).

The use of pure culture of bacteria offers advantage of detailed knowledge of dye degradation pathways, exact enzymology involved in it, formation of catabolic end products and their toxicity under a given set of cultural conditions. Moreover, it provides reproducible data output, and thus interpretation of experimental observations becomes easier (Khalid et al., 2012; Lalnunhlimi and Krishnaswamy, 2016). The present study deals with isolation, screening and identification of textile dye decolorizing bacterial cultures. The optimization of various physico-chemical parameters like inoculum size, $\mathrm{pH}$, temperature, dye concentration for the enhanced decolorization of Reactive Red HE8B by selected bacterial culture YPAG-9 was performed. Furthermore, the ability of bacterial culture to decolorize different synthetic dyes was investigated.

\section{Materials and Methods}

\section{Dyes and Chemicals}

Different textile dyes Reactive RedM5B (C.I. Reactive Red 2), Reactive Brown GR (C.I. Reactive Brown 18), Acid Green GLW (C.I. Acid Green 27), Reactive Red HE8B (C.I. Reactive Red 152), Acid Red 3BN (C.I. Acid Red 131), Reactive Blue 3R (C.I. Reactive Blue 28), Acid Red BB (C.I. Acid Red 128), Reactive Yellow MERL (C.I. Reactive Yellow 145), Reactive Violet 5R (C.I. Reactive Violet 5), Acid Orange II (C.I. Acid Orange 7), Reactive Orange HER (C.I. Reactive Orange 84) and Acid Red F2R (C.I. Acid Red 151)used in the present study were procured from $\mathrm{CAB}$ chemicals, Ankleshwar, Gujarat, India. All the dyes were of different chemical structures and were used without further purification. The high molecular weight sulfonated di-azodye Reactive Red HE8B was used as model dye for present study (Fig. 1). Bushnell Haas Medium, Nutrient agar, glucose, yeast extract, Luria Bertani broth and agar agar were purchased from Himedia Laboratories, Mumbai, India. All other chemicals and reagents used in the present study were of analytical grade. 


\section{Culture Media}

The isolation and dye decolorization experiments were performed using Bushnell Haas Medium (BHM) containing $\mathrm{gl}^{-}$ ${ }^{1}: \mathrm{MgSO}_{4} .7 \mathrm{H}_{2} \mathrm{O}, \quad 0.2 ., \quad \mathrm{CaCl}_{2} .2 \mathrm{H}_{2} 0, \quad 0.02$., $\mathrm{KH}_{2} \mathrm{PO}_{4}, 1.0$., $\mathrm{K}_{2} \mathrm{HPO}_{4}, 1.0$., $\left(\mathrm{NH}_{4}\right)\left(\mathrm{NO}_{3}\right)$, 1.0., $\quad \mathrm{FeCl}_{3}, 0.05$., and $\mathrm{pH} 7.0 \pm 0.2$ with glucose $(0.5 \% \mathrm{w} / \mathrm{v})$ and yeast extract $(0.05 \%$ $\mathrm{w} / \mathrm{v})$. The bacterial inoculum was prepared in Luria Bertani (LB) broth containing $\mathrm{g}^{-1}$ : casein enzymatic hydrolysates, 10.0,yeast extract, $5.0, \mathrm{NaCl}, 5.0$, and $\mathrm{pH}, 7.0 \pm 0.2$. The bacterial cultures were routinely maintained on LB agar.

\section{Isolation of dye decolorizing bacterial cultures}

The dye decolorizing bacterial strains were isolated from contaminated soil samples obtained from different sites of common effluent treatment plant (CETP), Nandesari, Vadodara, Gujarat, India. The soil samples $(1.0 \mathrm{~g})$ were added to $250 \mathrm{ml}$ Erlenmeyer flasks containing $100 \mathrm{ml}$ BHM + glucose $(0.5 \% \mathrm{w} / \mathrm{v})+$ yeast extract $(0.05 \% \mathrm{w} / \mathrm{v})$ and100 $\mathrm{mg} \mathrm{l}^{-1}$ Reactive Red HE8B. All the flasks were incubated under static condition at $30^{\circ} \mathrm{C}$ for 2 weeks. Five milliliter of enriched cultures showing decolorization of Reactive Red HE8Bwas transferred to 100 $\mathrm{ml}$ fresh BHM medium. Repeated transfers in fresh dye containing media were performed till stable dyedecolorizing bacterial cultures were obtained.

The final enriched cultures showing consistent growth and decolorization activity were serially diluted and plated on BHM agar plates containing Reactive Red HE8B $\left(100 \mathrm{mg} \mathrm{l}^{-1}\right)$. After incubation, different bacterial colonies with distinct morphological characteristics were picked up and purified by regular subculture. The isolated pure bacterial strains were maintained on LB agar slants.

\section{Screening of dye decolorizing bacterial cultures}

The isolated bacterial cultures were screened for the decolorization of Reactive Red HE8B under submerged condition. Each bacterial culture was cultivated in LB broth for $24 \mathrm{~h}$. A $10 \% \quad(\mathrm{v} / \mathrm{v})$ inoculum of individual bacterial strains with uniform cell density $\left(\mathrm{OD}_{600} \quad 0.5\right)$ was transferred to respective $250 \mathrm{ml}$ Erlenmeyer flasks containing $150 \mathrm{ml} \mathrm{BHM} \mathrm{+} \mathrm{glucose}(0.5 \%$ $\mathrm{w} / \mathrm{v})+$ yeast extract $(0.05 \% \mathrm{w} / \mathrm{v})$ and Reactive Red HE8B(100 mg l-1 $)$. All the flasks were incubated under static condition at $30^{\circ} \mathrm{C}$ for $72 \mathrm{~h}$. The aliquots were withdrawn from different flasks at regular time intervals and analyzed for growth and decolorization. Based on percent decolorization, the potential bacterial cultures were selected for further dye decolorization experiments.

\section{Identification of selected bacterial cultures}

The potential bacterial cultures showing highest decolorization of the dyes were identified on the basis of morphological, cultural, physiological and biochemical characteristics. The morphological properties included cell size, shape, arrangement and staining reaction. The cultural properties considered were size, shape, margin, elevation, texture, color of isolated colonies on nutrient agar plate. The physiological and biochemical properties of selected bacterial cultures were evaluated by indole, methyl red, Voges-Proskauer, catalase, oxidase, urease, nitrate reduction test, citrate utilization test, $\mathrm{H}_{2} \mathrm{~S}$ production test, growth on triple sugar iron agar slant etc. The ability to ferment various sugars like dextrose, lactose, maltose, mannitol, xylose, sucrose, fructose, arabinose, galactose etc. was also assessed. Based on 
comparative analysis of the observed characteristics with the standard description of bacterial strains in Bergey's Manual of Systematic Bacteriology, the bacterial cultures were identified upto species level.

\section{Establishment of optimum conditions for decolorization}

Optimization of various physico-chemical parameters $(\mathrm{pH}$, temperature, inoculum size, dye concentration) for maximum color removal was performed using single factor at a time methodology. The decolorization studies were performed using various inoculums size $(1,2,5,7,10,12,15 \%$ $(\mathrm{v} / \mathrm{v}))$, different dye concentration $(50,100$, $\left.150,200,250,300 \mathrm{mg} \mathrm{l}^{-1}\right), \mathrm{pH}$ values $(4,5,6$, $7,8,9,10)$ and temperature $(15,20,30,37$, $\left.42,50^{\circ} \mathrm{C}\right)$. The decolorization of various textile dyes by selected bacterial cultures was studied under optimum culture condition.

\section{Decolorization analysis}

The decolorized samples $(2 \mathrm{ml})$ collected at regular time intervals were centrifuged at $10,000 \mathrm{rpm}$ for $10 \mathrm{~min}$. The cell free supernatants were scanned in the range of 200 to $800 \mathrm{~nm}$ using UV-Visible spectrophotometer (SHIMADZU UV-1800, Japan).

The residual dye concentration in the sample was determined from the absorbance values using the calibration curve for absorbance versus dye concentration obtained by plotting the corresponding maximum absorbance in the UV-visible spectra at different concentrations of dye. Dye concentration of decolorized sample was quantified by comparing its absorbance with the absorbance of known concentrations and this was used to calculate percentage decolorization using the following formula:
Decolorization $(\%)=\left(\mathrm{A}_{\mathrm{I}}-\mathrm{A}_{\mathrm{F}} / \mathrm{A}_{\mathrm{I}}\right) \times 100$ where, $\mathrm{A}_{\mathrm{I}}=$ Initial absorbance, $\mathrm{A}_{\mathrm{F}}=$ Final absorbance.

\section{Data analysis}

All the experiments were performed in triplicates and the data presented is in the form of mean value. The standard deviation was calculated using the mean values and remained within the range of $\pm 10 \%$.

\section{Results and Discussion}

\section{Isolation, screening and identification of dye decolorizing bacterial cultures}

The bacterial cultures with an efficient color removal potential of textile azo dyes were isolated from soil samples contaminated with dyes. It is expected that site snear the CETP harbor several microorganisms which are capable to co-exist with higher toxic levels of pollution. The enrichment culture technique led to the isolation of 19 bacterial strains showing morphologically distinct colony characteristics on BHM agar plates containing100 mg $\mathrm{l}^{-1}$ Reactive Red HE8B. These bacterial isolates were designated as YPAG-1 to YPAG-19. The isolated bacterial strains were screened for the decolorization of dye Reactive Red HE8B (100mg $\mathrm{l}^{-1}$ ) in submerged condition. The color removal efficiency in terms of percent decolorization by isolates is depicted in Table 1. The isolate YPAG-9 showed highest decolorization of Reactive Red HE8B (86.36 $\pm 1.3 \%$ ) in $48 \mathrm{~h}$. The isolate YPAG-17 was found to be second most efficient culture showing $66.51 \pm 0.4 \%$ decolorization followed by isolates YPAG-3 (64.18 \pm $1.3 \%)$, YPAG-7(62.67 $\pm 1.7 \%)$ and YPAG$14(61.70 \pm 0.9 \%)$.Nevertheless the isolates YPAG-2, YPAG-4, YPAG-10 and YPAG16 exhibited lesser color removal efficiency in the range of $17.12 \pm 0.7 \%$ to $35.60 \pm$ 
$0.9 \%$. The isolation of dye decolorizing bacterial cultures from dye contaminated soil, sludge and an industrial effluent is reported by many researchers (Wang et al., 2009; Mohamed 2016). The potential dye decolorizing bacterial isolate YPAG-9 was identified on the basis of morphological, cultural, physiological and biochemical properties. The isolate YPAG-9 was Gram negative, motile, non endospore forming rods. The isolate YPAG-9 was able to grow on basal medium such as Nutrient agar to form medium to large sized, irregular, slightly raised colonies with irregular margins. The colonies were smooth with greenish colored pigmentation. Different physiological and biochemical propertiesof isolate YPAG-9 used for identification are listed in Table 2.

By comparing above results with the standard results of bacteria in Bergey's Manual of Systematic Bacteriology, the isolate YPAG-9 was identified as Pseudomonas aeruginosa and its taxonomical classification listed in Table 3.

\section{Establishment of optimum operational conditions for decolorization of RR HE8B}

\section{Effect of static and shaking condition}

The present study was conducted to evaluate the effect of incubation conditions on decolorization of Reactive Red HE8B by the isolate YPAG-9. The isolate exhibited effective color removal activity under static condition than shaking condition (Fig. 3). Under static condition, $87.63 \pm 2.1 \%$ decolorization of Reactive Red HE8B was obtained, whereas shaking condition showed only $46.12 \pm 1.9 \%$ color removal by the isolate YPAG-9 in $48 \mathrm{~h}$ (Fig. 4).The decolorization efficiency of isolate YPAG-9 was 1.9 times higher in static condition as compared to shaking condition. The obtained results suggested that the decolorization of the dye was significantly correlated with dissolved oxygen content; lesser the amount of dissolved oxygen, faster the color removal of the dye. Therefore, the facultative anaerobic condition was found to be more appropriate for the decolorization enhancing color removal performance of the isolate YPAG9. Many reports suggested that the reductive cleavage of azo bond is inhibited in the presence of dissolved oxygen primarily owing to the competition in the oxidation of reduced electron carriers like NADH between oxygen and azo group as electron acceptor (Asad et al., 2007; Wang et al., 2009).

In aerobic condition, the presence of highredox-potential electron acceptor oxygen may lead to the inhibition of dye reduction mechanism (Pearce et al., 2003). In support to our findings, similar results have been reported by Ghodake et al., (2011), wherein they showed that the decolorization of mono-azo dye Amaranth by Acinetobacter calcoaceticus NCIM 2890 was faster in static condition compared to shaking condition.

\section{Effect of inoculum size}

The decolorization efficiency of the isolate YPAG-9 was monitored at different inoculum concentrations ranging from 1.0 to $15.0 \%(\mathrm{v} / \mathrm{v})$. The decolorization of Reactive Red HE8B was $17.10 \pm 1.5 \%$ at $1.0 \%$ inoculum sizein $48 \mathrm{~h}$. A positive trend of decolorization of the dye with inoculum size was observed in the range of $1.0-10.0 \%$ with maximum decolorization $(88.54 \pm 2.4 \%)$ at $10.0 \%$ inoculum size (Fig. 5). Any further increase in inoculum size did not affect the decolorization performance of the isolate YPAG-9. The removal of Reactive Red HE8B was $85.35 \pm 1.9 \%$ and $84.14 \pm 2.6 \%$ at $12.0 \%$ and $15.0 \%$ inoculum size respectively. 
Since the bacterial number is a critical parameter for biological decolorization process, decline in bacterial population results in low decolorization rate along and prolonged decolorization time. An excess inoculum on the other hand leads to rapid depletion of nutrients and accumulation of toxic wastes which adversely affect bacterial growth and decolorizing activity (Moosvi et al., 2005). The decolorization of $50 \mathrm{mg} \mathrm{l}^{-1}$ Malachite Green was highest at $10 \%$ inoculum of Kocuriarosea MTCC 1532 (Parshetti et al., 2006). In the present study, the decolorization efficiency of the isolate YPAG-9 increased 3.27 folds at $10.0 \%$ inoculum as compared to $1.0 \%$ inoculum size, suggesting an optimum biomass requirement for effective decolorization of Reactive Red HE8B.

\section{Effect of pH}

In order to assess the effect of $\mathrm{pH}$, the decolorization of Reactive Red HE8B by the isolate YPAG-9 was performed in the range of $\mathrm{pH} 4.0-10.0$. The highest decolorization of the dye $(86.19 \pm 1.2 \%)$ was achieved at $\mathrm{pH}$ 7.0 in $48 \mathrm{~h}$ (Fig. 6). The dye removal capacity of the isolate was $68.52 \pm 2.3 \%$ and $74.25 \pm 1.4 \%$ at $\mathrm{pH} 6.0$ and 9.0 respectively. Nevertheless, the decrease in the decolorization of Reactive Red HE8B was evident at $\mathrm{pH} 4.0(28.14 \pm 2.3 \%)$ and $\mathrm{pH} 10.0$ $(33.75 \pm 1.4 \%)$. However, the color removal performance increased 2.12 fold as the $\mathrm{pH}$ of the medium was raised from 5.0 to 7.0.

Similarly, Chang et al., (2001) also reported 2.5 times increment in decolorization rate with a rise of $\mathrm{pH}$ from 5.0 to 7.0 using Pseudomonas luteola. Since various biological activities of the organisms are affected by hydrogen ion concentration, the major effect of $\mathrm{pH}$ on the decolorization of dye may be attributed to the transport of dye molecules across the cell membrane influencing overall color removal performance (Kodam et al., 2005). The previous reports exist showing higher decolorization of Direct Brown II and Alizarin Red S by different bacterial strains at optimum $\mathrm{pH}$ of 7.0 (Illanjiam and Arunachalam, 2011; Illakkiam et al., 2016).

\section{Effect of temperature}

The temperature is a factor of paramount importance for all processes associated with microbial viability, including the remediation of water and soil (Saratale et al., 2011). In the present study, the decolorization of Reactive Red HE8B by the isolate YPAG-9 was studied in the range of $15-50^{\circ} \mathrm{C}$. As shown in Fig. 7 the obtained decolorization at $15^{\circ} \mathrm{C}$ incubation was $28.63 \pm 2.7 \%$. The linear relationship between incubation temperature and color removal was observed in the temperature range of 15 to $30^{\circ} \mathrm{C}$ with a maximum decolorization $87.32 \pm 1.1 \%$. However, further increase in temperature resulted in the reduction of decolorization activity of isolate YPAG-9. The decolorization of the dye was $48.14 \pm 1.6 \%$ and $20.75 \pm 2.1 \%$ at $45^{\circ} \mathrm{C}$ and $50^{\circ} \mathrm{C}$ respectively.

Maximum color removal activity of the isolate at $30^{\circ} \mathrm{C}$ may be owing to higher bacterial growth along with larger production and activity of enzymes associated with color removal. Moreover, higher respiration and substrate metabolism at optimum temperature could result into faster decolorization rate. The decline in decolorization rate at higher temperature $\left(37-50^{\circ} \mathrm{C}\right)$ can be attributed to the loss of cell viability or to the denaturation of dye decolorizing enzyme such as azoreductase (Mate and Pathade, 2012). Our findings are in accordance with previously reported literature (Guo et al., 2008) explaining better decolorization of Reactive Brilliant Red K2BP by Halomonas GTW at $30^{\circ} \mathrm{C}$. 


\section{Effect of initial dye concentration}

The decolorization of Reactive Red HE8B by the isolate YPAG-9 was investigated in the range of initial dye concentration (50$300 \mathrm{mgl}^{-1}$ ) under static incubation condition. The results depicted in Figure 8 demonstrated that maximum decolorization of the dye $(87.64 \pm 2.1 \%)$ was obtained at $100 \mathrm{mg} \mathrm{l}^{-1}$ concentration in $48 \mathrm{~h}$. The color removal performance of the isolate decreased with the increase in dye concentration thereafter; $55.41 \pm 2.6 \%$ decolorization of the dye was observed at $300 \mathrm{mg} \mathrm{l}^{-1}$. However, the decolorization rate increased from 0.9 to $3.46 \mathrm{mgdyel}^{-1} \mathrm{~h}^{-1}$ with the increase in initial dye concentration from
50 to $300 \mathrm{mg} \mathrm{l}^{-1}$ indicating the stability and color removal capacity of isolate YPAG-9 at higher dye concentrations. This finding was consistent with previous studies reported by Khalid et al., (2008) wherein an inverse relationship between the decolorization by Shewanella putrefaciens and the initial dye concentrations was observed.Higher toxicity of dye to viable cells, inadequate biomass population for the uptake of higher concentrations of dye and blockage of active sites of enzymes by dye molecule may be the probable reasons for decrease in decolorization performance of microorganisms at higher dye concentrations.

Table.1 Decolorization of Reactive Red HE8B (100 $\left.\mathrm{mg}^{-1}\right)$ by isolated bacterial cultures under submerged condition

\begin{tabular}{|c|c|}
\hline Bacterial isolate & \% Decolorization \\
\hline YPAG-1 & $45.90 \pm 0.8$ \\
\hline YPAG-2 & $17.12 \pm 0.7$ \\
\hline YPAG-3 & $64.18 \pm 1.3$ \\
\hline YPAG-4 & $30.78 \pm 1.1$ \\
\hline YPAG-5 & $49.76 \pm 0.6$ \\
\hline YPAG-6 & $53.71 \pm 2.2$ \\
\hline YPAG-7 & $62.67 \pm 1.7$ \\
\hline YPAG-8 & $59.48 \pm 0.7$ \\
\hline YPAG-9 & $86.36 \pm 1.3$ \\
\hline YPAG-10 & $35.60 \pm 0.9$ \\
\hline YPAG-11 & $52.68 \pm 0.8$ \\
\hline YPAG-12 & $57.34 \pm 2.1$ \\
\hline YPAG-13 & $50.07 \pm 2.1$ \\
\hline YPAG-14 & $61.70 \pm 0.9$ \\
\hline YPAG-15 & $42.82 \pm 1.5$ \\
\hline YPAG-16 & $34.62 \pm 2.3$ \\
\hline YPAG-17 & $66.51 \pm 0.4$ \\
\hline YPAG-18 & $70.01 \pm 1.2$ \\
\hline YPAG-19 & $58.46 \pm 1.6$ \\
\hline
\end{tabular}


Table.2 Identification characteristics of bacterial isolate YPAG-9

\begin{tabular}{|c|c|}
\hline Characteristics & Result \\
\hline Gram stain reaction & Gram - ve \\
\hline Shape & Rod \\
\hline Motility & + \\
\hline Endospore formation & - \\
\hline Indole production & - \\
\hline Methyl Red Test & - \\
\hline Voges-ProskauerTest & - \\
\hline Citrate utilization & + \\
\hline Lysine decarboxylase & + \\
\hline Ornithine decarboxylase & + \\
\hline Urease & - \\
\hline Catalase & + \\
\hline Oxidase & + \\
\hline Phenylalanine deamination & - \\
\hline Nitrate reduction & + \\
\hline $\mathrm{H}_{2} \mathrm{~S}$ production & - \\
\hline Esculin hydrolysis & - \\
\hline Starch hydrolysis & - \\
\hline Gelatin hydrolysis & - \\
\hline \multicolumn{2}{|l|}{ Acid from } \\
\hline Glucose & + \\
\hline Adonitol & - \\
\hline Lactose & - \\
\hline Maltose & - \\
\hline Mannitol & - \\
\hline Sucrose & - \\
\hline Xylose & - \\
\hline Arabinose & + \\
\hline Sorbitol & - \\
\hline Rafifinose & - \\
\hline D- Fructose & - \\
\hline Galactose & - \\
\hline $\begin{array}{cc}\text { TSI Test } & \text { Slant } \\
\text { Butt } \\
\text { Gas production } \\
\mathrm{H}_{2} \mathrm{~S} \text { production }\end{array}$ & $\begin{array}{c}\text { Alkaline (Pink) } \\
\text { Acidic (yellow) } \\
- \\
-\end{array}$ \\
\hline Growth on Mac Conkey's agar & $\begin{array}{l}\text { Pale yellow lactose non- } \\
\text { fermenting colony }\end{array}$ \\
\hline
\end{tabular}

+ indicates positive growth/ present; - indicates no growth/absent 
Table.3 Taxonomical classification of bacterial isolate YPAG-9

\begin{tabular}{|c|c|}
\hline Classification & Isolate YPAG-9 \\
\hline Kingdom & Bacteria \\
\hline Phylum & Proteobacteria \\
\hline Class & Gamma Proteobacteria \\
\hline Order & Pseudomonadales \\
\hline Family & Pseudomonadaceae \\
\hline Genus & Pseudomonas \\
\hline Species & aeruginosa \\
\hline
\end{tabular}

Table.4 Decolorization of different azo dyes by isolate YPAG-9

\begin{tabular}{|c|c|c|c|}
\hline Dye & $\boldsymbol{\lambda} \mathbf{m a x}(\mathbf{n m})$ & \% Decolorization & Time (h) \\
\hline Acid Orange II & 484 & $46.24 \pm 2.6$ & 60 \\
\hline Acid Red BB & 532 & $61.16 \pm 2.1$ & 48 \\
\hline Reactive Red M5B & 538 & $37.45 \pm 1.6$ & 48 \\
\hline Reactive Orange HER & 496 & $34.33 \pm 2.3$ & 60 \\
\hline Acid Red 3BN & 551 & $76.19 \pm 1.4$ & 48 \\
\hline Reactive Violet 5R & 560 & $80.64 \pm 1.2$ & 48 \\
\hline Reactive Yellow MERL & 410 & $28.07 \pm 2.3$ & 60 \\
\hline Acid Red F2R & 510 & $44.71 \pm 3.5$ & 48 \\
\hline Reactive Brown GR & 475 & $59.52 \pm 2.4$ & 60 \\
\hline Acid Green GLW & 617 & $69.41 \pm 3.3$ & 60 \\
\hline Reactive Blue 3R & 577 & $82.15 \pm 1.9$ & 48 \\
\hline
\end{tabular}

Fig.1 Model dye Reactive Red HE8B used in present study

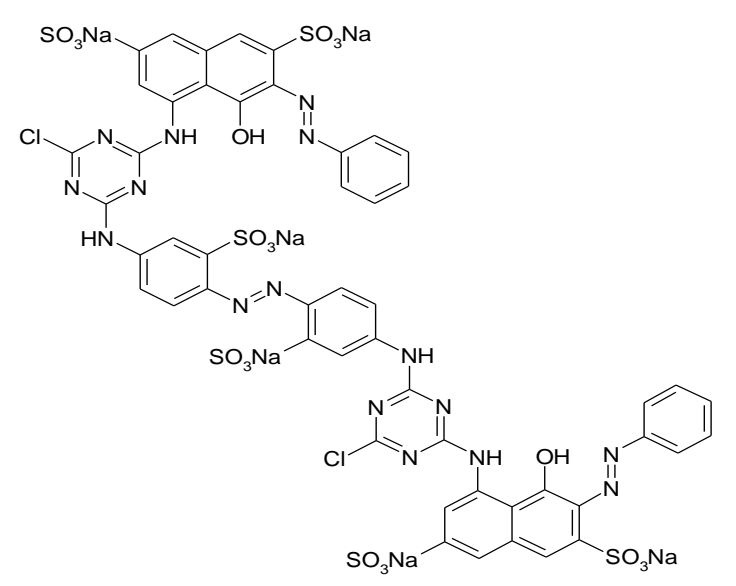

C.I. Name: Reactive Red 152

Molecular weight: 1752.11

Molecular formula: $\mathrm{C}_{52} \mathrm{H}_{30} \mathrm{Cl}_{2} \mathrm{~N}_{14} \mathrm{Na}_{6} \mathrm{O}_{20} \mathrm{~S}_{6}$

CAS No: $71870-80-5$

Maximum absorbance $\left(\lambda_{\max }\right): 548$ 
Fig.2 Growth characteristics of isolate YPAG-9 on Nutrient agar medium

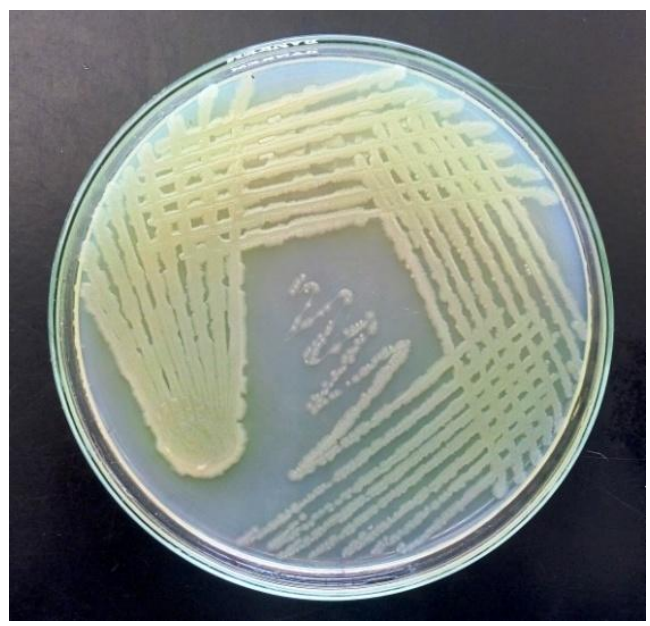

Fig.3 Decolorization of Reactive Red HE8B by isolate YPAG-9 (A) control and (B) decolorized dye sample after $48 \mathrm{~h}$ static incubation

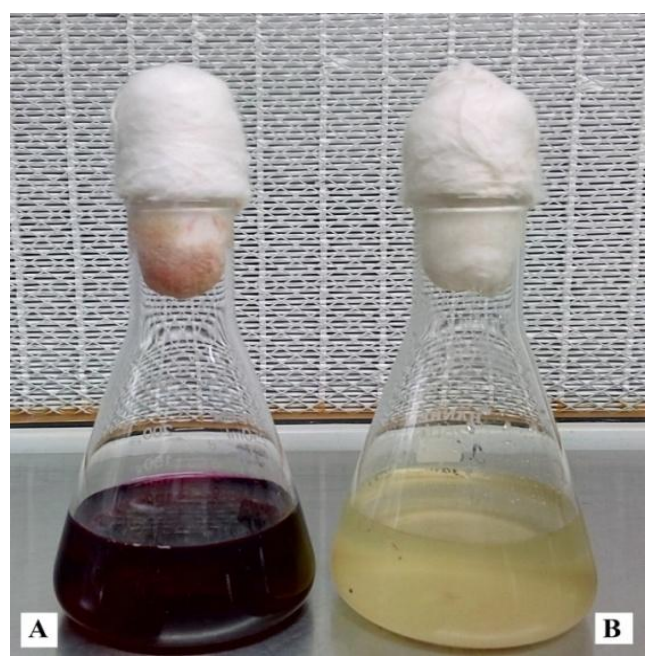

Fig.4 Decolorization of Reactive Red HE8B by isolate YPAG-9 under static and shaking incubation conditions

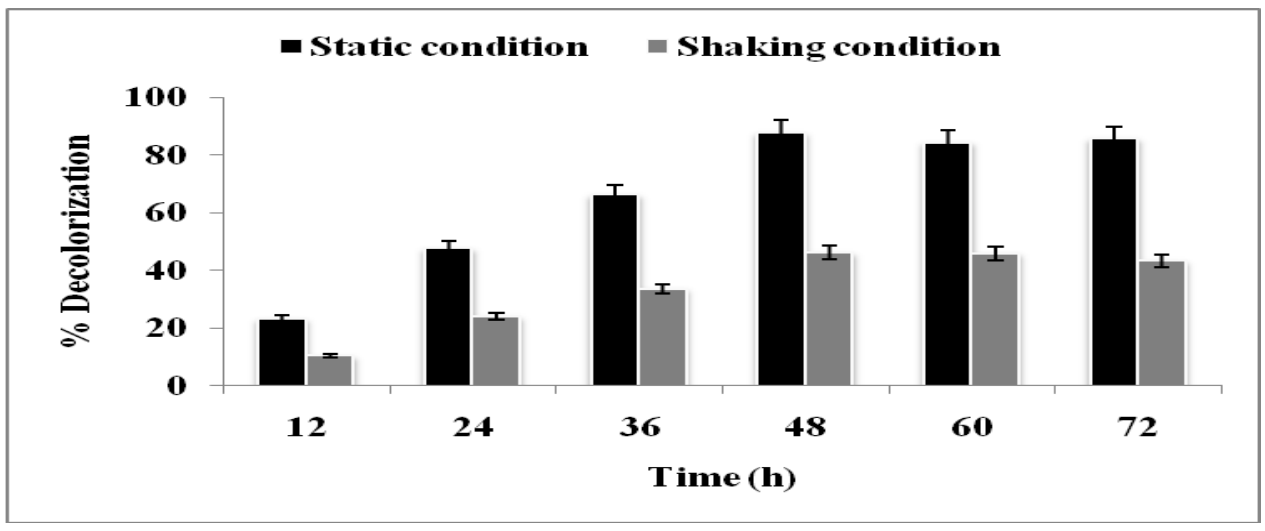


Fig.5 Effect of inoculum size on decolorization of Reactive Red HE8B by isolate YPAG-9.

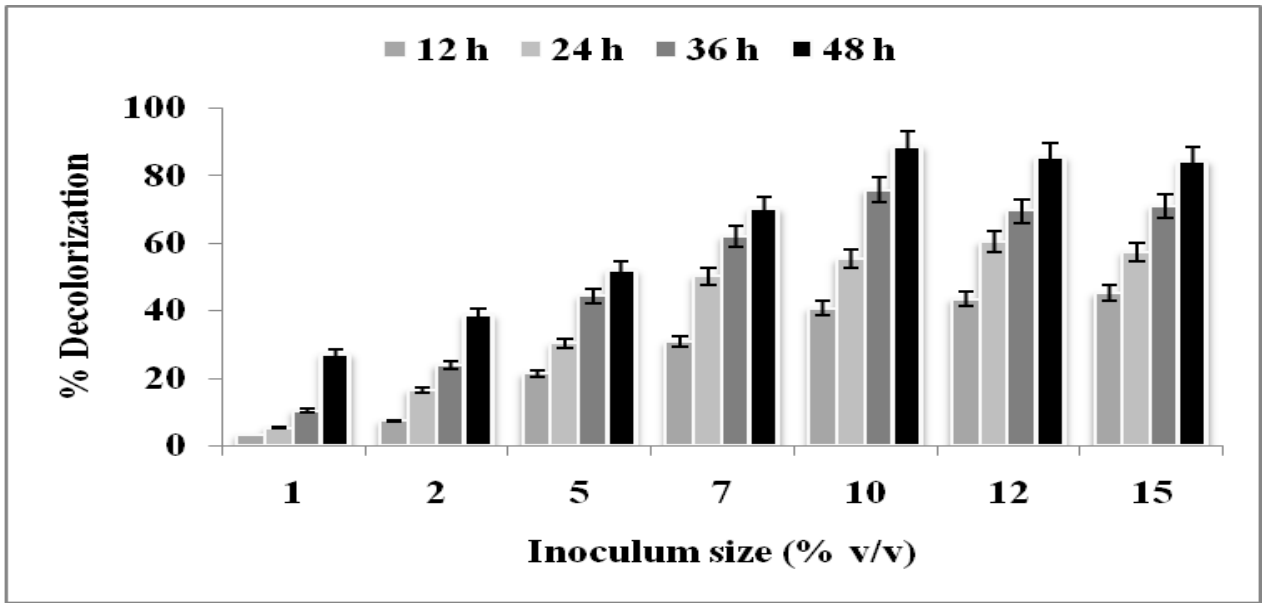

Fig.6 Effect of pH on decolorization of Reactive Red HE8B by isolate YPAG-9

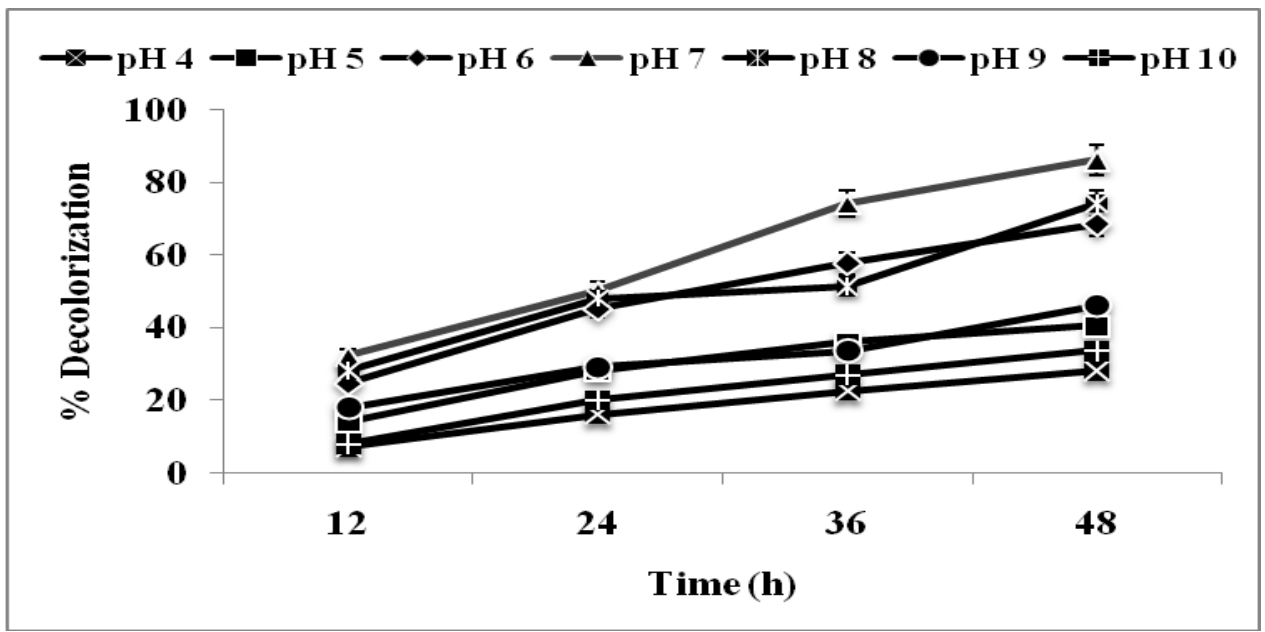

Fig.7 Effect of temperature on decolorization of Reactive Red HE8B by isolate YPAG-9

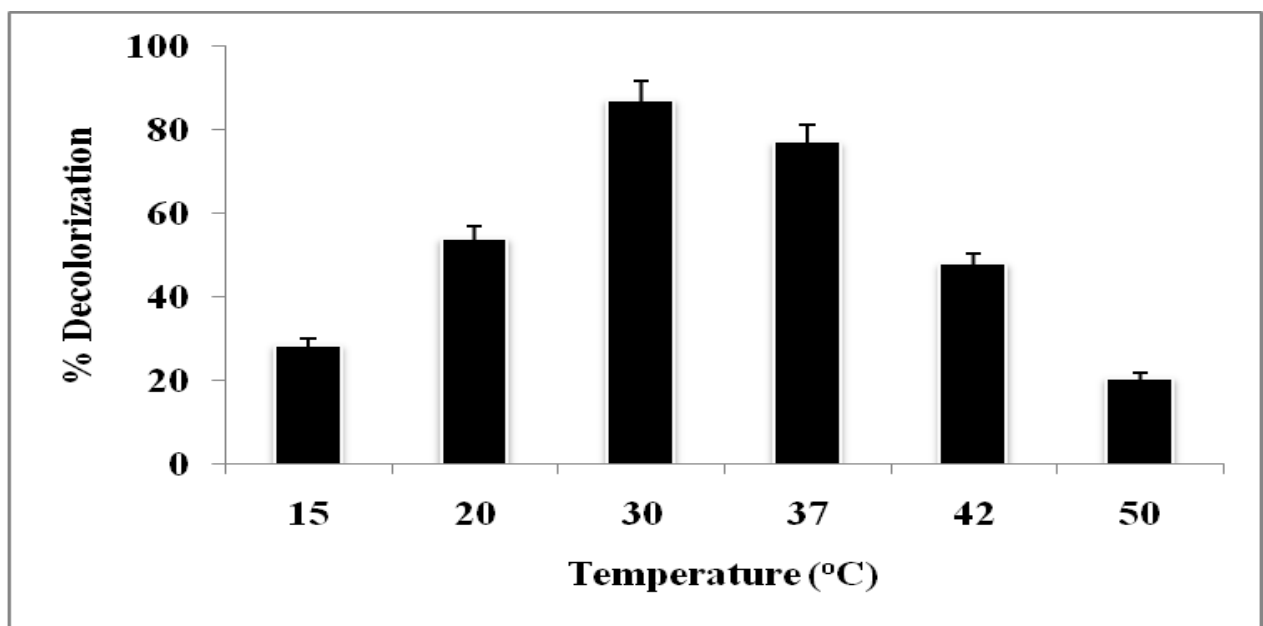


Fig.8 Effect of initial dye concentration on decolorization of Reactive Red HE8B by isolate YPAG-9

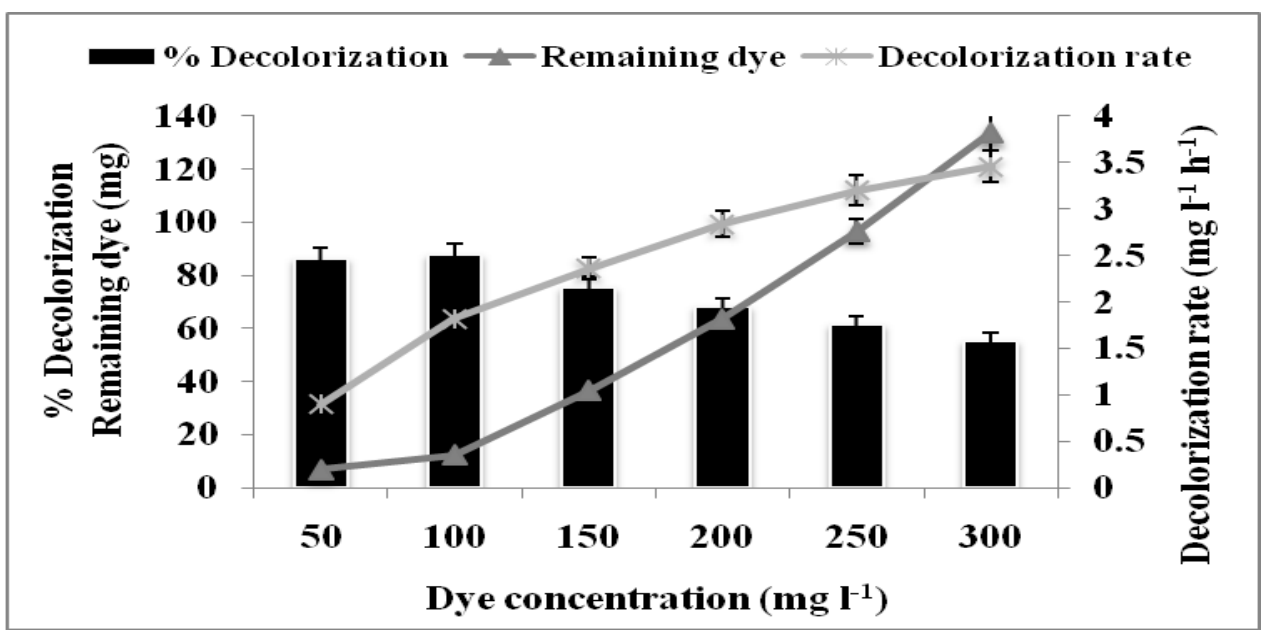

Moreover, the presence of sulfonic acid $\left(\mathrm{SO}_{3} \mathrm{H}\right)$ groups, which might acts as detergent inhibiting the growth and overall dye decolorization performance of bacteria (Tony et al., 2009). In contrast, very dilute dye solutions led to lower rate of dye decolorization probably owing to insufficient dye molecules that would be recognized by the dye reductase enzymes inside the cells (Pearce, 2003).

\section{Spectrum of dyes decolorized by isolate YPAG-9}

Large varieties of synthetic dyes are released in the industrial effluent. The ability of isolate YPAG-9 to decolorize different textile dyes was studied under submerged condition. The results presented in Table 4 indicated that the isolate decolorized dyes in varying extent. The considerable decolorization of Reactive Blue $3 \mathrm{R}$ and Reactive Violet $5 \mathrm{R}$ was achieved by the isolate in $48 \mathrm{~h}$. However, Reactive Yellow MERL was found to be most resistant for the decolorization followed by Reactive Orange HER and Reactive Red M5B with decolorization between 28 and $37 \%$ in $60 \mathrm{~h}$. This difference in decolorization pattern may be due to structural diversity of various dyes. Reports suggest that faster decolorization of dyes is obtained which chemical structure is simple as well as of low molecular weight. Whereas, highly substituted, high molecular weight dyes are hard to decolorize by microorganisms. Moreover, the extent of color removal is highly influenced by number of azo bonds and substitution of electron withdrawing groups $\left(-\mathrm{SO}_{3} \mathrm{H},-\mathrm{SO}_{2} \mathrm{NH}_{2}\right)$ in dye molecules (Sani and Banerjee 1999). The results thus indicate the capability of the isolate YPAG9 to decolorize different dyes and hence, its potential use in the treatment of multiple dye containing industrial effluents.

In conclusion, the present study portrays the potential of bacterial isolate YPAG-9 to decolorize sulfonated di-azodye Reactive Red HE8B. The isolate was identified as Pseudomonas aeruginosa. Maximum decolorization of the dye was achieved with $10 \%$ inoculum size at $\mathrm{pH} 7.0$ and $30^{\circ} \mathrm{C}$ under static incubation condition. The isolate YPAG-9 was able to decolorize higher concentrations of the dye as well as displayed the competency for effective decolorization of different textile dyes. Therefore, it is concluded that the isolate YPAG-9 holds good potential for the 
decolorization of dyes; further research could explore the ability of the isolate to develop viable and eco-friendly strategies for bioremediation of synthetic dyes from industrial waste water.

\section{References}

Ali, H. 2010. Biodegradation of synthetic dyes-A review. Water, Air, Soil Pollution, 213: 251-273.

Asad, S., Amoozegar, M.A., Pourbabaee, A.A., Sarbolouki, M.N., and Dastgheib, S.M.M. 2007. Decolorization of textile azo dyes by newly isolated halophilic and halotolerant bacteria. Biores. Technol., 98: 2082-2088.

Chang, J.S., Chou, C., Lin, P.J., Ho, J.Y., and $\mathrm{Hu}$ T.L. 2001. Kinetic characteristic of bacterial azo-dye decolorization by Pseudomonas luteola. Water Res., 35: 2841-2850.

Chen, G., Huang, M.H., Chen, L., and Chen, D.H. 2011. A batch decolorization and kinetic study of Reactive Black 5 by a bacterial strain Enterobacter sp.GY-1. Int. Biodeterioration\& Biodegradation, 65: 790-796.

Ekambaram, S.P., Perumal, S.S., and Annamalai, U. 2016. Decolorization and biodegradation of remazol reactive dyes by Clostridium species. 3 Biotech. DOI 10.1007/s13205-0150335-0.

Flores, Y., Flores, R., and Gallegos, A.A. 2008. Heterogeneous catalysis in the Fenton-type system reactive black 5/ $\mathrm{H}_{2} \mathrm{O}_{2}$. J. Mol. Catalysis A: Chem., 281: 184-191.

Franciscon, E., Zille, A., Garboggini, F.F., Silva, I.S., Paulo, A.C., and Durrant, L.R. 2009. Microaerophilic-aerobic sequential decolorization/ biodegradation of textile azo dyes by a facultative Klebsiella sp. strainVN31. Process Biochem., 44: 446-452.
Gahlout, M., Gupte, S., and Gupte, A. 2013. Optimization of culture condition for enhanced decolorization and degradation of azo dye Reactive Violet 1 with concomitant production of ligninolytic enzymes by Ganodermacupreum AG-1. 3Biotech. 3: 143-152.

Ghodake, G., Jadhav, U., Tamboli, D., Kagalkar, A., and Govindwar, S. 2011. Decolorization of textile dyes and degradation of mono-azo dye amaranth by Acinetobacter calcoaceticus NCIM 2890. Indian J. Microbiol., 51(4): 501-508.

Gnanapragasam, G., Senthilkumar, M., Arutchelvan, V., Sivarajan, P., and Nagarajan, S. 2010. Recycle in upflow anaerobic sludge blanket reactor on treatment of real textile dye effluent. World J. Microbiol. Biotechnol., 26: 1093-1098.

Guo, J., Zhou, J., Wang, D., Yang, J., and Li, Z. 2008. The new incorporation bio-treatment technology of bromoamine acid and azo dyes wastewaters under high-salt conditions. Biodegradation, 19: 9398.

Illakkiam, D., Subha, D., Ahila, V., and Geetha, N. 2016. Decolorization of alizarin red $\mathrm{s}$ dye by bacterial strains isolated from industrial effluents. Int. J. Plant, Animal and Environ. Sci., 6(1): 268-275.

Illanjiam, S., and Arunachalam, K.D. 2011. Biodegradation of azo dye Direct Brown II by Pseudomonas aeruginosa, Bacillus subtilis \& Pseudomonas putida. J. Pharmacy Res., 4: 2969-2974.

Kadam, A.A., Kamatkar, J.D., Khandare, R.V., Jadhav, J.P., and Govindwar, S.P. 2013. Solid- state fermentation: tool for bioremediation of adsorbed textile dyestuff on distillery industry 
waste-yeast biomass using isolated Bacillus cereus strain EBT1. Environ. Sci.Pollution Res., 20: 1009-1020.

Khalid, A., Arshad, M., and Crowly, D.E. 2008. Accelerated decolorization of structurally different azo dyes by newly isolated bacterial strains. Appl. Microbiol. Biotechnol., 78: 361-369.

Khalid, A., Kausar, F., Arshad, M., mahmood, T., and Ahmed, I. 2012. Accelerated decolorization of reactive azo dyes under saline conditions by bacteria isolated from Arabian seawater sediment. Appl. Microbiol. Biotechnol., 96: 1599-1606.

Khouni, I., Marrot, B., and Amar, R.B. 2011. Treatment of reconstituted textile wastewater containing a reactive dye in an aerobic sequencing batch reactor using a novel bacterial consortium. Separation and Purification Technol., 87: 110-119.

Kodam, K.M., Soojhawon, I., Lokhande, P.D., and Gawai, K.R. 2005. Microbial decolorization of reactive azo dyes under aerobic conditions. World J. Microbiol. Biotechnol., 21: 367-370.

Lalnunhlimi, S., Krishnaswamy, V. 2016. Decolorization of azo dyes (Direct Blue 151 and Direct Red 31) by moderately alkaliphilic bacterial consortium. Brazilian J. Microbiol., 47: 39-46.

Lang, W., Sirisansaneeyakul, S., Martins, L.O., Ngiwsara, L., Sakairi, N., Pathom-aree, W., Okuyama, M., Mori, H., and Kimura, A.2014. Biodecolorization of a food azo dye by the deep sea Dermacoccusabyssi MT1.1T strain from the Mariana Trench. J. Environ. Management, 132: $155-164$.

Liao, C.S., Hung, C.H., and Chao, S.L. 2013. Decolorization of azo dye reactive black $\mathrm{B}$ by Bacillus cereus strain HJ-1. Chemosphere, 90: 21092114.

Liu, W.X., Chao, Y.P., and Yang, X.Q. 2004. Biodecolorization of azo, anthraquinonic and triphenylmethane dyes by white-rot fungi and a laccasesecreting engineered strain. $J$. Industrial Microbiol. Biotechnol., 31: 127-132.

Machado, K.M., Compart, G.L.C.A., Morais, R.O., Rosa, L.H., and Santos, M.H. 2006. Biodegradation of Reactive textile dyes by Basidiomycetous fungi from Brazilian ecosystems. Brazilian J. Microbiol., 37: 481-487.

Mangaiyarkarasi A., Kavitha K., and Geetharamani D. 2015. Decolourization of Textile dye Effluent employing Pseudomonas mendocinaand Xanthomonas hortorum. Int. J. Biosci. Nanosci., 2(1): 5-19.

Mate, M.S., and Pathade, G. 2012. Biodegradation of C.I. Reactive Red 195 by Enterococcus faecalis strain YZ66. World J. Microbiol. Biotechnol., 28: 815-826.

Mohamed, W.S. 2016. Isolation and Screening of Reactive Dye Decolorizing Bacterial Isolates from Textile Industry Effluent. Int. J. Microbiol. Res., 7(1): 01-08.

Moosvi, S., Kehaira, H., and Madamwar, D. 2005. Decolorization of textile dye Reactive Violet 5 by a newly isolated bacterial consortium RVM 11.5. World J. Microbiol. Biotechnol., 21: 667-672.

Pajot, H.F., Delgado, O.D., de Fiqueroa, L, I., and Farina, J.I. 2011. Unravelling the decolorizing ability of yeast isolates from dye-polluted and virgin environments: an ecological and taxonomical overview. Antonie Van Leeuwenhoek, 99: 443-456. 
Parshetti, G., Kalme, S., Saratale, G., and Govindwar, S. 2006. Biodegradation of Malachite Green by Kocuriarosea MTCC 1532. Acta Chimica Slovenica, 53: 492-498.

Pearce C.I., Lloyd, J.R., and Guthrie, J.T. 2003. The removal of color from textile wastewater using whole bacterial cells: a review. Dyes and Pigments, 58: 179-196.

Przystas, W., Godlewska, E.Z., and Sota, E.G. 2012. Biological Removal of Azo and Triphenyl Dyes and Toxicity of Process By-Products. Water, Air, Soil Poll., 223: 1581-1592.

Rudakiya, D., and Pawar, K. 2014. Bioremediation potential of Comamonas acidovarans MTCC 3364 for the removal of sulfonated diazo dye Reactive Black B. Int. J. Agri. Environ. Biotechnol., 7: 525535.
Sani, R.K., and Banerjee, U.C. 1999. Decolorization of triphenylmethane dyes and textile and dye-stuff effluent by Kurthia sp. Enzyme and Microbial Technol., 24: 433-437.

Saratale, R.G., Saratale, G.D., Chang, J.S., and Gowindwar, S.P. 2011. Bacterial decolorization and degradation of azo dyes: A review. J. Taiwan Institute of Chem. Engineers, 42: 138-157.

Tony, B.D., Goyal, D., and Khanna, S. 2009. Decolorization of textile azo dyes by aerobic bacterial consortium. Int. Biodeterioration \& Biodegradation, 63: 462-469.

Wang, H. Su, J.Q., Zheng, X.W., Tian, Y., Xiong, X.J., and Zheng, T.L. 2009. Bacterial decolorization and degradation of the reactive dye Reactive Red 180 by Citrobacter sp. CK3. Int. Biodeterioration \& Biodegradation, 63: 395-399.

\section{How to cite this article:}

Yogesh Patel and Akshaya Gupte. 2016. Evaluation of Bioremediation Potential of Isolated Bacterial Culture YPAG-9 (Pseudomonas aeruginosa) for Decolorization of Sulfonated diazodye Reactive Red HE8B under Optimized Culture Conditions. Int.J.Curr.Microbiol.App.Sci. 5(8): 258-272. doi: http://dx.doi.org/10.20546/ijcmas.2016.508.027 